\title{
Binding specificities of mono- and polyclonal antibodies to the protozoan oyster pathogen Perkinsus marinus
}

\author{
Christopher F. Dungan ${ }^{1}$, Bob S. Roberson ${ }^{2}$ \\ ${ }^{1}$ Maryland Department of Natural Resources, Cooperative Oxford Laboratory, 904 S. Morris St, Oxford, Maryland 21654, USA \\ ${ }^{2}$ Microbiology Department, University of Maryland, College Park, Maryland 20742, USA
}

\begin{abstract}
In an effort to develop direct detection methods for Perkinsus marinus cells in host tissue and environmental samples, the production of both mono- and polyclonal antibodies specific for this apicomplexan oyster pathogen was attempted. A particulate hypnospore immunogen was isolated from infected oyster hemolymph following incubation in Ray's fluid thioglycollate medium. Polyclonal antisera produced in both mice and rabbits following immunization with this preparation exhibited high antibody titers for pathogen cell epitopes, but not for host oyster tissue epitopes. At least some antibodies to hypnospore antigenic determinants recognized common epitopes on trophozoite cells in infected oyster tissues, as well as on zoospores and other proliferative cells produced by incubation of infected oyster hemolymph in sterile seawater Polyclonal antibodies also recognized a diffusable, noncellular substance present in host oyster tissues in areas surrounding focal lesions. Rabbit polyclonal antibodies did not recognize 2 Dermocystidium species infecting salmonid fishes or Haplosporidium nelsoni infecting eastern oysters Crassostrea virginica. These antibodies did recognize many, but not all, Perkinsus species infecting selected molluscan hosts worldwide. Monoclonal antibodies produced to date apparently recognize epitopes unique to the hypnospore immunogen.
\end{abstract}

\section{INTRODUCTION}

Perkinsiosis caused by the apicomplexan protozoan Perkinsus marinus is currently the most widespread and lethal infectious disease of the eastern oyster, Crassostrea virginica. In spite of many investigations spanning some $40 \mathrm{yr}$, neither the pathogenesis of the disease, the life cycle of the pathogen, nor the dynamics and mechanisms of its dissemination are completely understood (Andrews 1988). At least 3 distinct cell types (trophozoites or aplanospores, prezoosporangia or hypnospores, and planonts or zoospores) are recognized as stages in the pathogen's life cycle. Not all stages are obligatory to maintenance or transmission of infections (Perkins 1988), and experimental laboratory infections have been reported following exposure of uninfected oysters to both the trophozoite stage (Mackin 1962) and the zoospore stage (Perkins 1988). Transmission of the disease to uninfected oysters has also been documented following exposure to infected Boonea impressa, a gastropod ectoparasite which may function as a vector (White et al. 1987).
Histological examination of fixed host tissues, or incubation of fresh tissues in a fluid thioglycollatebased medium, followed by staining and microscopic observation (Ray 1963), are the only currently available methods for detection of Perkinsus marinus. Of these 2 methods, some variation of Ray's fluid thioglycollate medium (RFTM) incubation method is usually favored as a diagnostic tool due to its greater sensitivity and relative ease by comparison to histological methods. Recent modifications of this assay which utilize a small hemolymph tissue sample provide a novel opportunity for nonacute determination of the disease status of live oysters (Gauthier \& Fisher 1990).

The utility of Ray's method is limited to detection of pathogen cells which will enlarge in RFTM. In the absence of independent verification methods, Ray's (1952) hypotheses that (1) all Perkinsus marinus cells enlarge, but (2) do not proliferate, during incubation have not been rigorously tested. Therefore, estimates of parasite tissue burdens by enumeration of RFTMinduced hypnospores in host tissue samples (Mackin 1962, Choi et al. 1989, Gauthier \& Fisher 1990) remain tenuous. 
In the higher latitude portions of the pathogen's range, overwintering tissue stages are thought to be refractile to enlargement induction in RFTM, and seasonal variability in the sensitivity of the assay is thought to underestimate population disease prevalences from samples taken during winter months (Andrews 1988). The efficacy of Ray's method for detection of Perkinsus marinus zoospores, or other dispersal stages thought to occur in enzootic waters, has not been established; no method exists for direct detection and enumeration of infectious particles in environmental samples

In an effort to overcome the limitations of existing methodologies, the production of antibodies for direct detection of this pathogen was attempted. It was anticipated that at least some pathogen-specific antigenic determinants would be expressed by all stages and pathogen cell types, and that antibodies binding to common epitopes would universally detect Perkinsus marinus cells, cell fragments, or extracellular products. The availability of specific antibodies is expected to permit definitive studies of the pathogen life cycle and the mechanisms of disease transmission by providing a direct means for localization, quantification, and purification of pathogen cells or components in experimental systems. Such antibodies are also expected to provide the basis for development of sensitive diagnostic immunoassays for direct detection and enumeration of pathogen cells in both host tissue and environmental samples.

Development of monoclonal antibodies (MABs) with specificity for universal epitopes common to all Perkinsus marinus cell types will provide investigators with unlimited quantities of standardized immunodetection reagents. Development of MABs specific for unique epitopes present on specific $P$. marinus cell types or subcellular components will provide useful reagents for studies of biochemical composition, gene expression, and physiology of various cell types postulated to function in the pathogen life cycle.

One recent report describes the failure of antisera produced by immunization of rabbits with a soluble perkinsus marinus hypnospore fraction to recognize in vivo pathogen cell types (Choi et al. 1991). The present report describes a method for isolation of a particulate hypnospore immunogen from the hemolymph of infected oysters, and its use in production of both mouse and rabbit polyclonal antibodies which bind to all known $P$. marinus cell types. Results of attempts to produce murine monoclonal antibodies with similar binding specificities are presented. The binding specificity of rabbit polyclonal antibodies for selected protozoan pathogens infecting a variety of aquatic hosts worldwide is also described.

\section{MATERIALS AND METHODS}

Oysters. Adult Crassostrea virginica used in this study were collected from natural populations around Chesapeake Bay, USA, during the course of annual disease surveys conducted by the Maryland Department of Natural Resources from 1989 to 1991. Random, 30-oyster subsamples from all populations were assayed for the presence of Perkinsus marinus infections by independently incubating both rectal and hemolymph tissue samples from each sampled individual in RFTM, followed by observation for enlarged pathogen cells.

Uninfected oysters were collected from a tributary of the Potomic River which had been historically free of Perkinsus marinus infections. Ten numbered oysters were aseptically dissected and several types of samples retained. Rectal and hemolymph tissues were assayed for $P$. marinus, as described above. A sample for histological examination was processed by standard methods. Approximate $1.0 \mathrm{~g}$ portions of ventral mantle tissue were individually frozen. Tissues from individual oysters in which no evidence of $P$. marinus infection was detected were employed as negative controls in assays described below.

Pathogen isolation and purification. Oysters from populations with high prevalences of heavily infected individuals were numbered, drilled at the valve margins adjacent to the adductor muscle, and placed in recirculating aquaria for $24 \mathrm{~h}$ prior to sampling. After dipping the drilled valve margin in a $10 \%(\mathrm{v} / \mathrm{v}) \mathrm{com}$ mercial bleach solution, a 1.0 to $3.0 \mathrm{ml}$ hemolymph sample was taken from the adductor muscle sinus of each individual, using a sterile syringe fitted with an 18 gauge needle.

Hemolymph was distributed at $0.5 \mathrm{ml}$ well ${ }^{-1}$ into sterile, 24-well tissue culture plates. To the hemolymph sample in each well was added $1.5 \mathrm{ml}$ of RFTM supplemented with 200 units $\mathrm{ml}^{-1}$ of nystatin, 500 units $\mathrm{ml}^{-1}$ of penicillin, and $500 \mu \mathrm{g} \mathrm{ml^{-t }}$ of streptomycin. Plates were sealed with sterile mylar plate sealers, incubated at $25^{\circ} \mathrm{C}$ for 5 to $7 \mathrm{~d}$, and all wells were observed daily with an inverted microscope. Wells containing large numbers of Perkinsus marinus hypnospores, and which remained free of contaminating protozoans, fungi or bacteria, were selected for harvesting.

Mylar plate sealers were wiped with $95 \%$ EtOH. Hypnospores were then harvested by puncturing the mylar film with an 18 gauge needle mounted on a sterile syringe, and using the plunger to triturate the contents of wells. The resulting suspensions were transferred to sterile, centrifuge tubes. Harvested wells were washed once with a sterile centrifugation buffer (EPBS, pH 7.5) containing $0.1 \mathrm{M}$ sodium phosphate, $0.2 \mathrm{M}$ sodium chloride, and $1.0 \mathrm{mM}$ disodium ethy- 
lenediaminetetraacetate (EDTA). Cells harvested by washing were pooled with other harvested cell suspensions.

Hypnospores were separated from host oyster components by repeated differential centrifugation at decreasing centrifugal force, using a modification of the methods of Chu \& Greene (1989). Supernates were always discarded, and cell pellets were resuspended in approximately 20 volumes of sterile EPBS. Briefly, the suspension harvested from wells was pelleted for $8 \mathrm{~min}$ at $750 \times g$. The pellet was then washed 3 times at $475 \times g$ for $5 \mathrm{~min}, 3$ times at $280 \times g$ for $3 \mathrm{~min}$, and 3 times at $150 \times g$ for $3 \mathrm{~min}$.

The washed pellet was resuspended in 20 volumes of EPBS containing $2.0 \%(\mathrm{w} / \mathrm{v})$ paraformaldehyde and fixed at $4{ }^{\circ} \mathrm{C}$ overnight. Following fixation, cells were pelleted at $240 \times g$ for $3 \mathrm{~min}$, and washed 3 times in EPBS at $150 \times g$ for $3 \mathrm{~min}$. Prior to the last wash, the number of hypnospores in suspension was estimated by a hemacytometer count. Cells were washed twice in sterile, $0.85 \% \mathrm{NaCl}$ for $3 \mathrm{~min}$ at $150 \times g$. The pellet was resuspended in sterile $0.85 \% \mathrm{NaCl}$ to give a final concentration of $1 \times 10^{6}$ or $1 \times 10^{7}$ cells $\mathrm{ml}^{-1}$, aliquoted in sterile $1.0 \mathrm{ml}$ cryules, and frozen at $-70^{\circ} \mathrm{C}$ until used for immunizations. For staining, samples of hypnospore immunogen cells were allowed to settle onto the surface of poly-L-lysine-coated microscope slides, fixed, washed, and stored at $4{ }^{\circ} \mathrm{C}$ in EPBS.

Hypnospores for use as ELISA plate-coating antigen were recovered from oysters whose sampled hemolymph contained high concentrations of pathogen cells. These oysters were aseptically separated from their valves, dipped in $10 \%(\mathrm{v} / \mathrm{v})$ commercial bleach for surface decontamination, immersed whole in $20 \mathrm{ml}$ of antimicrobial-supplemented RFTM in sterile, $50 \mathrm{ml}$, polyethylene tubes, and incubated at $20^{\circ} \mathrm{C}$ for 10 to $14 \mathrm{~d}$. Oyster meats and culture medium were then pooled and homogenized for $15 \mathrm{~s}$ in a sterile blender. The homogenate was passed through 3 sterile, stainless steel screens $(500,250$ and $150 \mu \mathrm{m}$ mesh openings, respectively), and the filtrate processed as for hypnospores from hemolymph, with the following differences. Following fixation, hypnospores were washed 3 times in EPBS at $150 \times g$, quantified, aliquoted at $1 \times 10^{6}$ cells ml ${ }^{-1}$, and stored at $4{ }^{\circ} \mathrm{C}$ in EPBS containing $0.02 \%(w / v)$ sodium azide.

For production of motile zoospores, as well as nonmotile proliferative cells, 200 to $500 \mu \mathrm{l}$ of infected oyster hemolymph were added to tissue culture flasks containing $5.0 \mathrm{ml}$ of $25 \mathrm{ppt}$, sterile, artificial seawater (SASW) fortified with 500 units $\mathrm{ml}^{-1}$ of penicillin and $500 \mu \mathrm{g} \mathrm{ml} \mathrm{m}^{-1}$ of streptomycin. Flasks were incubated unsealed at $25^{\circ} \mathrm{C}$. Motile zoospores and other nonmotile proliferative cells were harvested by removal and replacement of SASW in flasks. Harvested cells were immobilized by filtration onto the surface of a poly-L-lysine-coated, $1.0 \mu \mathrm{m}$ pore size, black polycarbonate membrane filter (Poretics, Livermore, CA, USA) and fixed with $2.0 \%(\mathrm{w} / \mathrm{v})$ paraformaldehyde in EPBS. Alternatively, culture water containing motile cells was placed in a poly-L-lysine-coated chamber slide and held at $4^{\circ} \mathrm{C}$ overnight to immobilize cells prior to fixation.

Immunization and antiserum production. The hypnospore immunogen was thawed, vortexed, and either

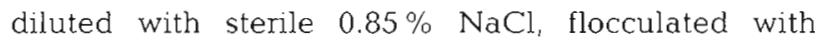
$\mathrm{Al}(\mathrm{OH})_{3}$ (Harlow \& Lane 1988), or emulsified with one volume of Freund's Complete Adjuvant (FCA) before injection. Two New Zealand white rabbits were immunized with Perkinsus marinus hypnospores as follows:

Day 1: Prebleed, $10 \mathrm{ml}$. Inject with $1.0 \mathrm{ml}$ of FCA/ hypnospore emulsion containing $3.0 \times 10^{5}$ cells, and administered in 2 scapular subcutaneous (sc) injections, and 2 hindquarter intramuscular (im) injections.

Day 14: Boost, sc, with $0.5 \mathrm{ml} \mathrm{Al}(\mathrm{OH})_{3}$-flocculated hypnospores at $6.0 \times 10^{5}$ cells $\mathrm{ml}^{-1}$.

Day 28: Boost, sc, with $0.5 \mathrm{ml} \mathrm{Al}(\mathrm{OH})_{3}$-flocculated hypnospores at $6.0 \times 10^{5}$ cells $\mathrm{ml}^{-1}$.

Day 33: Test bleed, $10 \mathrm{ml}$.

Day 42: Boost, sc, with $0.5 \mathrm{ml}$ of hypnospores in sterile, $0.85 \% \mathrm{NaCl}$ at $6 \times 10^{5}$ cells $\mathrm{ml}^{-1}$.

Day 47: Test bleed, $25 \mathrm{ml}$.

Day 48: Test bleed, $25 \mathrm{ml}$.

Rabbits were boosted and bled on a monthly cycle until $300 \mathrm{ml}$ of serum had been collected and stored at $-70^{\circ} \mathrm{C}$. Serum antibody titers for both $P$. marinus hypnospore and normal oyster tissue epitopes were determined for each serum sample by endpoint dilution ELISA assays. Preimmune sera were used as controls.

Monoclonal antibody production. BALB/C mice were hyperimmunized with the hypnospore immunogen until serum antibody titers to the immunogen exceeded 1:5000 in the hybridoma screening assay. Initial intraperitoneal (ip) injection of $1.0 \times 10^{5}$ cells in FCA, followed by 2 ip boosts with 1.0 to $3.0 \times 10^{5}$ cells in sterile saline, failed to produce the desired serum titers. Subsequent sc boosts, both with and without FCA, resulted in elevated antibody titers. A prefusion, sc/ip boost of $4.0 \times 10^{5}$ cells was administered $4 \mathrm{~d}$ prior to each of 2 separate fusions. Blood collection from splenocyte donor mice was maximized at splenectomy, and recovered serum was employed at a $10^{-3}$ dilution as a positive control in hybridoma screening assays. Preimmune sera were employed, at the same dilution, as negative controls

Murine splenocyte/plasmacytoma hybridomas were generated by standard methods (Harlow \& Lane 1988). 
Splenocytes were fused with either X63-Ag8.653 or SP2/ O-Ag14, BALB/c-derived, mouse plasmacytoma cells using polyethyleneglycol (PEG 1500) as the fusogen, and a splenocyte: plasmacytoma ratio of $1: 1$. Fusion products were plated in RPMI-1640 medium supplemented with $20 \%(\mathrm{v} / \mathrm{v})$ fetal bovine serum, $10 \%(\mathrm{v} / \mathrm{v})$ Origen $^{B}$ (IGEN, Rockville, MD), $1.0 \mathrm{mM}$ oxaloacetate, $0.2 \mathrm{U} \mathrm{ml}^{-1}$ insulin, $0.45 \mathrm{mM}$ pyruvate, $100 \mu \mathrm{M}$ hypoxanthine, $16 \mu \mathrm{M}$ thymidine, and $0.4 \mu \mathrm{M}$ aminopterin, at a density calculated to generate less than one viable hybridoma per well in 96-well tissue culture plates, and incubated in a $5.0 \%$ $\mathrm{CO}_{2}$ atmosphere. Splenocyte feeder cells were not

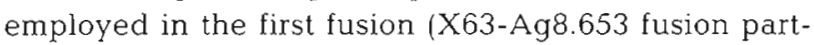
ner), but were employed in the second fusion (SP2/OAg14 fusion partner).

Wells with positive hybridoma growth were screened for the presence of Perkinsus marinus-specific monoclonal antibody using a hypnospore-based ELISA assay. Positive hybridomas were expanded and cloned at least twice by limiting dilution in 96-well tissue culture plates. Cloned hybridomas were expanded and cultured continuously until sufficient conditioned medium had been acquired for evaluation of MABs.

ELISA assays. Rabbit serum antibody titers against both normal oyster tissue antigens and Perkinsus marinus hypnospore antigens were estimated by endpoint dilution ELISA assays in which antigens were adsorbed to polystyrene ELISA plates. Normal oyster tissue antigen-coated plates were prepared by homogenizing $1.0 \mathrm{~g}$ of normal oyster mantle tissue in $20 \mathrm{ml}$ of $0.15 \mathrm{M}$ phosphate-buffered saline (PBS), and allowing $50 \mu$ of the homogenate to adsorb to virgin wells for $1 \mathrm{~h}$. To enhance particle retention, hypnospore-coated plates were precoated for $30 \mathrm{~min}$ with $1.0 \mathrm{mg} \mathrm{ml}$ poly-L-lysine (molecular weight = 100 000), washed once with PBS, and $5.0 \times 10^{3}$ hypnospores in $50 \mu \mathrm{l}$ of PBS were adsorbed to each well for $1 \mathrm{~h}$.

Following antigen adsorption, unoccupied binding sites on the support plastic were blocked for $1 \mathrm{~h}$ with PBS containing $2.0 \%(\mathrm{w} / \mathrm{v})$ bovine serum albumin (BSA), $0.05 \%(\mathrm{v} / \mathrm{v})$ Tween-20 and $0.02 \%(\mathrm{w} / \mathrm{v})$ sodium azide. Plates were washed once with PBS containing $0.05 \%$ Tween-20 (PBST), and $50 \mu \mathrm{l}$ of standard rabbit serum dilutions from all test bleeds were applied to wells. Standard rabbit serum dilutions representing $\log _{10}$ serum dilution factors of $-2.0,-3.0,-4.0,-4.3,-4.6$, $-4.9,-5.2$, and -5.5 were made in PBST containing $1.0 \%(\mathrm{w} / \mathrm{v})$ BSA (PBST/BSA). Dilutions of preimmune sera and serum diluent alone were employed as controls. Serum dilutions were incubated in wells for $1 \mathrm{~h}$ at $20^{\circ} \mathrm{C}$. Wells were washed 3 times with PBST, and bound rabbit immunoglobulin was labeled using $50 \mu$ l of an affinity-purified, horseradish peroxidase antibody conjugate $\left(0.4 \mu \mathrm{g} \mathrm{Ig} \mathrm{ml} \mathrm{m}^{-1}\right)$ incubated for $1 \mathrm{~h}$ at $20^{\circ} \mathrm{C}$. Following 3 washes with PBST, the enzyme conjugate was detected using $0.5 \mathrm{mg} \mathrm{ml}^{-1}$ of $o$-phenylenediamine (OPD) and $0.015 \%(\mathrm{v} / \mathrm{v}) \mathrm{H}_{2} \mathrm{O}_{2}$ in $0.15 \mathrm{M}$ citrate-phosphate buffer ( $\mathrm{pH}$ 5.0). Color development was stopped after 10 min with 1 volume of $2.0 \mathrm{~N} \mathrm{H}_{2} \mathrm{SO}_{4}$, and absorbances read at $492 \mathrm{~nm}$. Titers were recorded as the $-\log _{10}$ of the endpoint serum dilution.

Hybridomas were screened using an antigen/antibody-capture assay in which the capture antigen was Perkinsus marinus hypnospores immobilized as described above. Isotyping of MABs was performed using an antibody/antibody-capture ELISA format and a commercial subisotyping kit (Hyclone, Logan, UT, USA) according to the manufacturer's directions. Monoclonal antibody titers in hybridoma culture media were quantified relative to that of the $10^{-3}$ dilution of mouse polyclonal antiserum employed as a positive control. Two-fold dilutions of hybridoma culture media and of the polyclonal control serum were applied to the same capture antibody-coated ELISA plates used in subisotyping assays. Assay conditions were identical to those employed for subisotyping assays, except that a polyclonal enzyme conjugate with specificity for all murine immunoglobulin heavy and light chains was employed for detection. In all MAB ELISA assays, hybridoma-conditioned culture medium was incubated for 12 to $16 \mathrm{~h}$ at $4{ }^{\circ} \mathrm{C}$ in ELISA plate wells coated with the capture antibody or antigen, prior to application of $2^{\circ}$ antibodies.

Immunofluorescence and immunohistochemical assays. Tissues from both infected and uninfected oysters were fixed in Davidson's AFA fixative, embedded in paraffin, and sectioned by standard methods. Prior to immunostaining, sections were deparaffinized and rehydrated through a graded ethanol series. After equilibration in $\mathrm{PBS}$, sections were blocked for $30 \mathrm{~min}$. Blocked sections were incubated for 30 to $60 \mathrm{~min}$ in rabbit or mouse antiserum diluted to either $10^{-2}$ or $10^{-3}$ in PBST/BSA, or in undiluted hybridoma culture medium (RPMI-20). The same culture medium, conditioned by the parent plasmacytoma cells used in fusions, was employed as a negative control reagent in MAB assays. Pre-immune sera were employed as negative control reagents in polyclonal antibody assays. Uninfected oyster tissue sections were employed as negative control samples in assays of both types of $1^{\circ}$ antibodies.

Sections were washed with PBST and incubated with conjugated, species immunoglobulin-specific $2^{\circ}$ antibodies for $30 \mathrm{~min}$. Incubation of duplicate sections in which blocking buffer was substituted at the $1^{\circ}$ antibody incubation step was always employed as a control for spurious binding of conjugated $2^{\circ}$ antibodies, autofluorescence, or endogenous enzyme activity.

For immunofluorescence, FITC-conjugated $2^{\circ}$ anti-

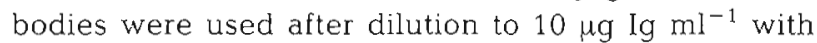


PBST/BSA. The FITC-stained slides were washed with PBST, counterstained $30 \mathrm{~s}$ with $0.01 \%$ (w/v) Evan's blue, mounted in buffered glycerol, and observed with an epifluorescence microscope.

For immunohistochemical analyses, horseradish peroxidase-conjugated $2^{\circ}$ antibodies were used after dilution to $0.4 \mu \mathrm{g} \mathrm{Ig} \mathrm{ml}^{-1}$ with PBST/BSA. Sections were washed with PBST and the reporter enzyme detected using cobalt-enhanced diaminobenzedine. $4 \mathrm{HCl}$ (DAB) at $0.5 \mathrm{mg} \mathrm{ml}^{-1}$ in 0.1 M Tris buffer ( $\mathrm{pH} 7.6$ ) containing $0.01 \% \mathrm{H}_{2} \mathrm{O}_{2}$ and $8.0 \mathrm{mM} \mathrm{Co}\left(\mathrm{C}_{2} \mathrm{H}_{3} \mathrm{O}_{2}\right)_{2}(\mathrm{KPL}$, Gaithersburg, MD) for $5 \mathrm{~min}$ at $20^{\circ} \mathrm{C}$. Immunostained sections were counterstained with Mayer's hematoxylin and eosin ( $H \& E$ ) and coverslipped as permanent preparations.

Cytological preparations of hypnospores, zoospores, and proliferating cells immobilized on membranes or slides were fixed, washed with PBST, blocked, and fluorescence or enzyme immunostained as described above, using similar controls. Membrane-immobilized cells were fixed, rinsed, blocked, and stained by sequential passage of solutions through membranes clamped in the same holders used in the sample collection. Stained membranes were removed from holders and mounted in buffered glycerol on slides for microscopic observation.

Antibody binding to related pathogens. Paraffin blocks containing fixed tissues of aquatic hosts infected with selected protozoan pathogen species were solicited from investigators worldwide. Upon arrival, blocks were sectioned by standard methods and enzyme immunostained as a group by methods described above, using $\mathrm{DAB}$-cobalt as the reporter chromophore. In addition to the use of known infected and uninfected Crassostrea virginica sections as batch controls, duplicate sections of each solicited sample were processed identically, except that one member of each pair was not exposed to the $1^{\circ}$ rabbit antibody. Pathogens in each sample were scored as reactive or nonreactive with the $1^{\circ}$ rabbit antibody after comparison of immunostained sections with all positive and negative controls. Host species, pathogen species, references, and sample sources for this material are listed in Table 1.

\section{RESULTS}

\section{Pathogen isolation and purification}

Yields of Perkinsus marinus hypnospores from pooled hemolymph samples averaged $2.2 \times 10^{5}$ hypnospores $\mathrm{ml}^{-1}$, with a range of 1.0 to $2.9 \times 10^{5}$ hypnospores $\mathrm{ml}^{-1}$ of hemolymph, among 5 different groups of oysters which were used. The double harvesting of 24well plates resulted in an estimated harvest efficiency greater than $95 \%$ of all hypnospores present. Hypnospores adhered tenaciously to both glass and plastic surfaces, in spite of the chelation of divalent cations, and some processing losses resulted. Microscopic observation of purified hypnospore preparations revealed that the only particulates present in the suspension were $P$. marinus hypnospores. A low proportion of hypnospores harvested from hemolymph incubations was capable of zoosporulation when a sample taken prior to fixation was incubated in $25 \mathrm{ppt}$ SASW at $25^{\circ} \mathrm{C}$. Germ tube formation was frequently observed, and actively moving zoospores within sporangium walls were less frequently observed.

Table 1. Pathogen species, host species, sample sources, and references for histological samples of aquatic host tissues infected with selected protozoan pathogens, which were tested for binding by Rabbit $\alpha$ Perkinsus marinus antiserum

\begin{tabular}{|lllll|}
\hline Pathogen species & Host species & $\begin{array}{c}\text { Geographic } \\
\text { source }\end{array}$ & Sample source & Reference \\
\hline Haplosporidium nelsoni & Crassostrea virginica & MD, USA & S. V. Otto & Haskin et al. (1966) \\
Perkinsus marinus & Crassostrea virginica & AL. USA & F. G. Kern & Mackin et al. (1950) \\
Perkinsus marinus & Crassostrea virginica & MA, USA & E. J. Lewis & E. J. Lewis et al. (unpubl.) \\
Perkinsus sp. & Crassostrea virginica & HI, USA & F. G. Kern & Kern et al. (1973) \\
Perkinsus sp. & Macoma balthica & MD, USA & F. G. Kern & Andrews (1954) \\
Perkinsus sp. & Mya arenaria & MD, USA & S. M. McLaughlin & Andrews (1954) \\
Perkinsus olseni & Haliotis laevigata & Australia & R. J. G. Lester & Lester et al. (1990) \\
Perkinsus sp. & Katelysia rhytiphora & Australia & R. J. G. Lester & Lester et al. (1990) \\
Perkinsus sp. & Tridacna maxima & Australia & C. L. Goggin & Goggin \& Lester (1987) \\
Perkinsus sp. & Chama pacificus & Australia & C. L. Goggin & Goggin \& Lester (1987) \\
Perkinsus sp. & Anadara trapezia & Australia & C. L. Goggin & Lester et al. (1990) \\
Perkinsus sp. & Tridacna crocea & Australia & C. L. Goggin & Goggin \& Lester (1987) \\
Perkinsus atlanticus & Ruditapes decussatus & Portugal & C. Azevedo & Azevedo (1989) \\
Perkinsus karlssoni & Argopecten irradians & NB, Canada & S. E. McGladdery & McGladdery et al. (1991) \\
Dermocystidium sp. & Salmo salar & CA, USA & R. P. Hedrick & Hedrick et al. (1989) \\
Dermocystidium salmonis & Oncorhynchus tshawytscha & OR, USA & R. Olson & Pauley (1967) \\
& & & & \\
\hline
\end{tabular}


Motile zoospores were never observed to escape the confining hypnospore wall, and their motility ceased after approximately $10 \mathrm{~d}$.

The average yield of Perkinsus marinus hypnospores from whole animal tissue homogenates was $4.4 \times 10^{6}$ hypnospores oyster ${ }^{-1}$. Microscopic observation of supernates discarded during centrifugation revealed that a large, but unquantified, percentage of hypnospores remained in suspension, and losses resulted. Microscopic examination of processed hypnospore suspensions revealed that oyster gill bars were present as a minor particulate contaminant in an otherwise pure preparation.

\section{Immunization and antiserum production}

Serum antibody titers for both Perkinsus marinus hypnospore and normal oyster tissue epitopes, which were typical of rabbits injected with the hypnospore immunogen, are shown in Fig. $1 . \log _{10}$ titers of antibodies binding to pathogen hypnospores increased rapidly and stabilized at 4.6 by the third sample ( $60 \mathrm{~d}$ ). Apparent titers for antibodies binding to normal oyster tissue epitopes were measured in preimmune sera, but did not increase with repeated exposure to the hypnospore immunogen, and are interpreted as a nonspecific binding artifact. These data indicate that such rabbit antisera will reliably detect pathogen epitopes at dilutions as high as $5 \times 10^{-4}$, but will not detect normal oyster tissue epitopes at dilutions greater than $10^{-2}$. The data also indicate no induction of tolerance in rabbits after repeated exposure to the immunogen by the described schedule. Hyperimmunized BALB/C mice showed similar titers for hypnospore antigens once subcutaneous exposure was begun.

\section{Monoclonal antibody production}

Of 2 fusion protocols employed, that which utilized the SP2/0-Ag14 parent and splenocyte feeder cells in plating the fusion gave superior results. While the first fusion produced only 10 viable hybridomas, 1 of which was positive in the screening assay, the second fusion produced 512 hybridomas, 25 of which were positive in the screening assay. MABs secreted by stable hybridomas were predominantly of IgM isotype. Despite their consistent ability to bind to pathogen hypnospores in ELISA assays, and immunoglobulin concentrations 1 to 32 times that of a $10^{-3}$ dilution of the murine polyclonal antiserum successfully used as a positive control in both ELISA and immunohistochemical assays, none of the MABs bound to in vivo pathogen cell types when tested by immunostaining of histological sections, and are presumed to recognize epitopes unique to the hypnospore immunogen.

\section{Immunostaining of Perkinsus marinus cells}

Both murine and rabbit polyclonal antisera raised against Perkinsus marinus hypnospores specifically bound to in vivo pathogen stages in histological sections from infected oysters. A large, mature trophozoite within mantle tissue is shown fluorescence immunostained in Fig. 2. In addition to the pathogen cytoplasm, antibodies strongly labeled the pathogen nuclear membranes and endosome. The eccentric vacuole characteristic of mature trophozoite cells was unstained. Fig. 3 shows a single trophozoite cell which demonstrates the relative intensity of antibody labeling of the pathogen nucleus, and which is internalized within a circulating hemocyte. Fig. 4 shows a 4 -cell

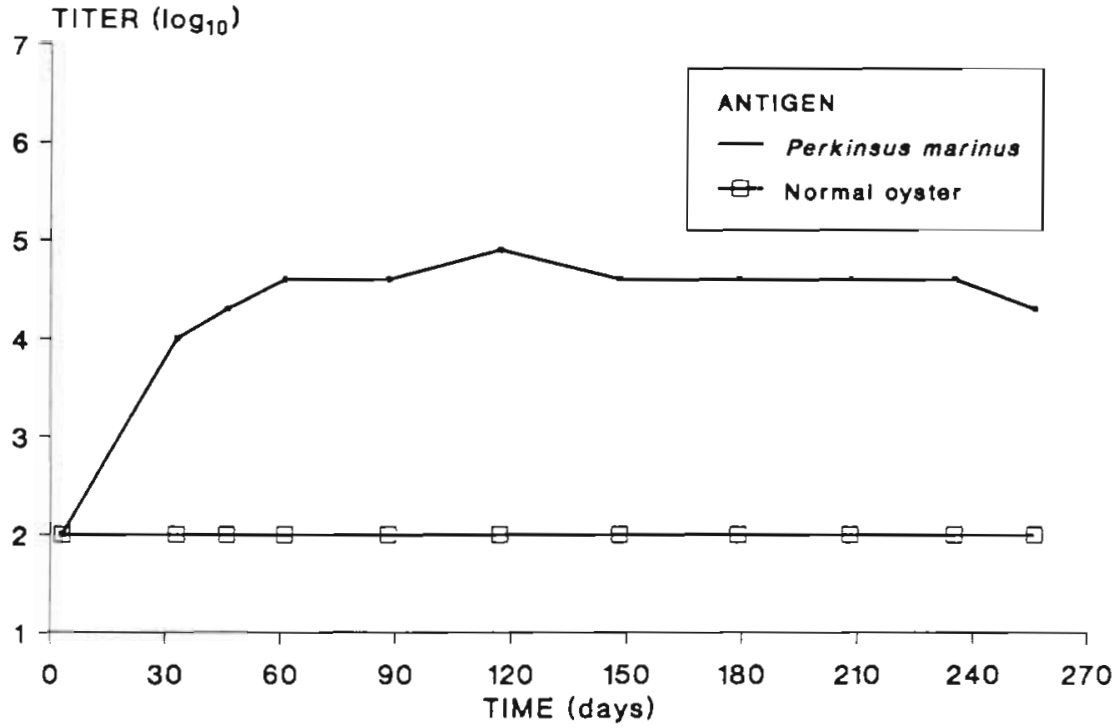

Fig. 1 Typical serum titers of rabbit antibodies binding to Perkinsus marinus hypnospores and to normal Crassostrea virginica tissue epitopes induced by regular injection of a hypnospore immunogen. Titers to hypnospore epitopes rise rapidly and stabilize without evidence of tolerance induction. Apparent low titers to oyster tissue epitopes are confirmed as spurious by their detection in preimmune serum and their failure to increase with exposure to the immunogen. Titers are expressed as $-\log _{10}$ of the endpoint serum dilution 
cluster of pathogen cells which appear to have recently completed plasmotomy within a circulating hemocyte, and in which antibody labeling was confined to cell surfaces. In Fig. 5, immature trophozoite cells forming a rosette in mantle epithelium show paired, fluorescent structures suggestive of karyotomy, within their nuclei.
Low-intensity background staining of normal oyster components in these and other micrographs is due to the red, nonspecific fluorescence of the Evan's blue counterstain, which is easily distinguished from the higher intensity, green fluorescein signal. Remarkably, considering that hemocyte cellular antigens were the
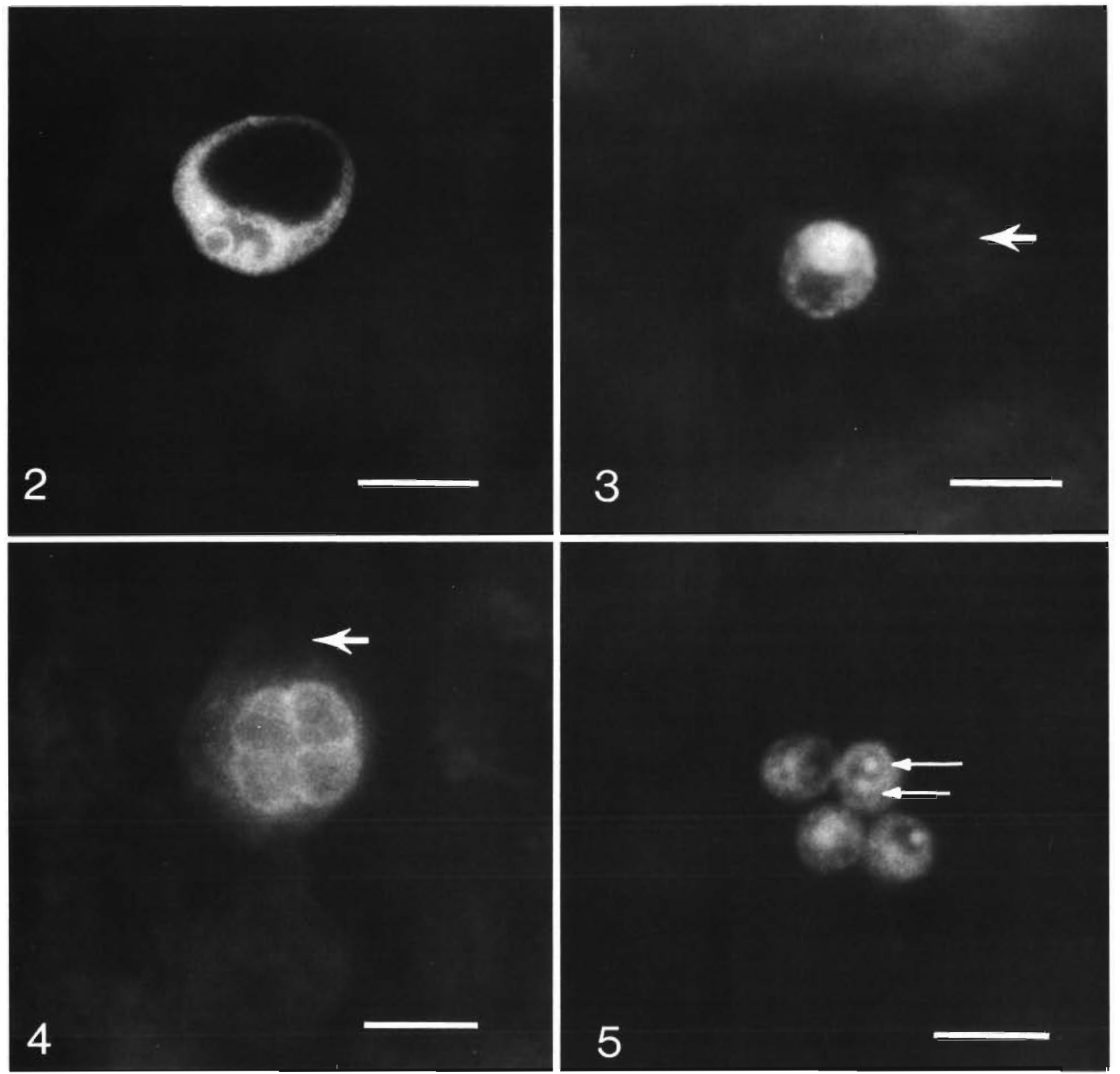

Figs. 2 to 5. Crassostrea virginica infected by Perkinsus marinus. Fluorescence immunostained histological sections of infected oyster tissues counterstained with Evan's blue. Fig. 2. Mature trophozoite in mantle tissue showing antibody binding to pathogen cell cytoplasm, nuclear membranes, and endosome. Typical eccentric vacuole remains unstained. Scale bar $=10 \mu \mathrm{m}$. Fig. 3. Trophozoite within a circulating hemocyte showing relative intensity of antibody binding to pathogen nucleus and cytoplasm. Arrow indicates hemocyte nucleus. Scale bar $=5 \mu \mathrm{m}$. Fig. 4. Surface-immunostained cluster of pathogen cells within one circulating hemocyte appear to have recently divided. Arrow indicates hemocyte nucleus. Scale bar $=5 \mu \mathrm{m}$. Fig. 5 . Four-cell rosette of immature trophozoites in mantle epithelium. Paired nuclear endosomes (arrows) in several cells suggest incipient karyotomy. Scale bar $=5 \mu \mathrm{m}$ 


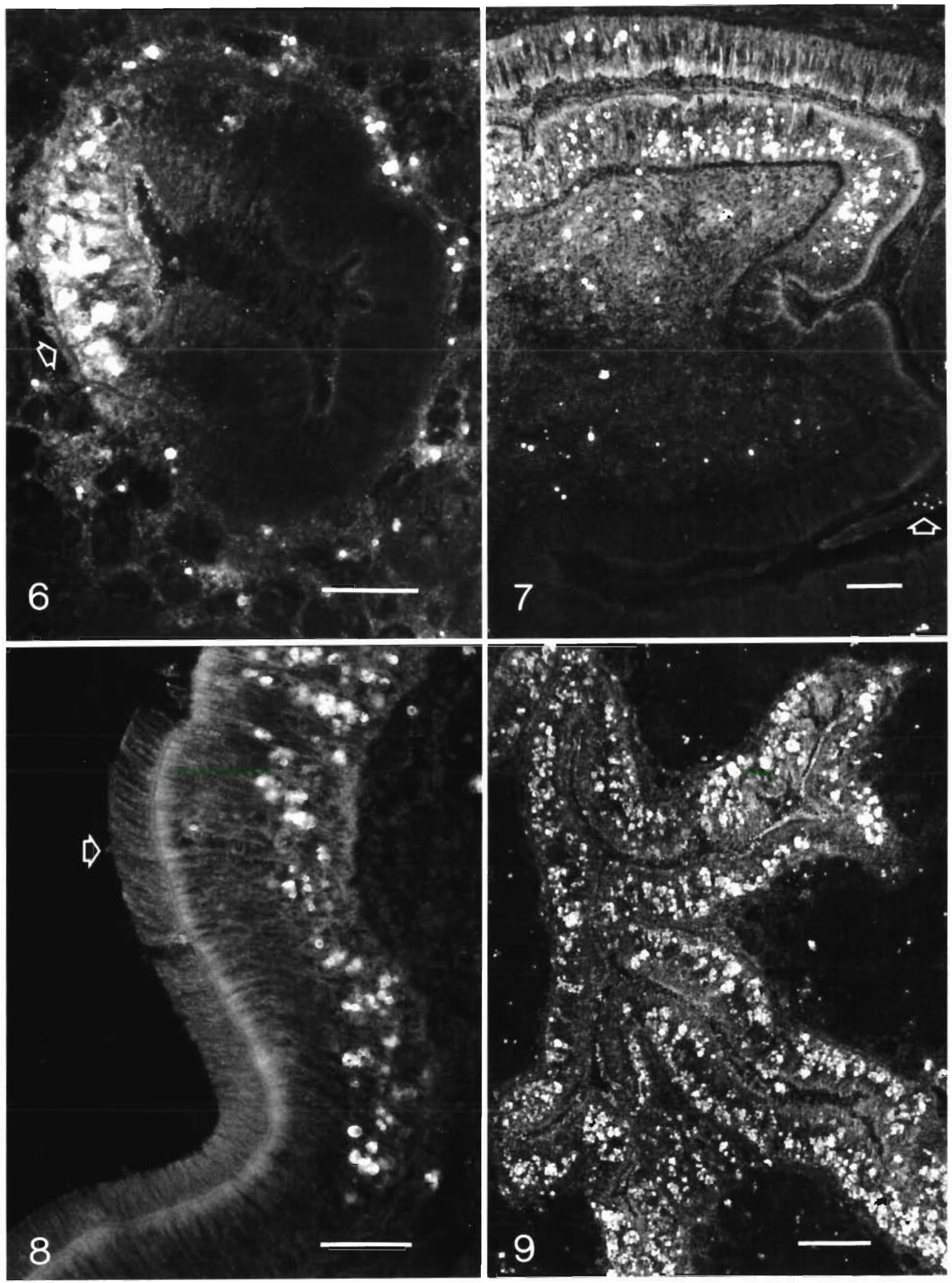


most likely host component to have copurified with the hypnospore immunogen, no evidence of antibody binding to hemocytes was observed.

In addition to these pathogen cell types, which have been previously described (Mackin 1962, Perkins 1988), one or more epitopes which occurred as small (ca $0.5 \mu \mathrm{m}$ ) particles or as a diffusable, nonparticulate substance were localized in areas immediately surrounding focal lesions, and were stained by rabbit polyclonal antibodies. Whether immunoreactive, noncellular small particulates represent soluble substances coagulated during fixation is not known.

Fig. 6 shows a cross-sectioned digestive gland distributing duct with a focal epithelial lesion and a diffuse infection of the connective tissue at the epithelial basal lamina. Small fluorescent particles were associated especially with the cytoplasm and apical surfaces of epithelial cells involved by the focal lesion. The concentration of these particles in the duct epithelium decreased with distance from the focal lesion, and they were almost entirely absent from the uninvolved epithelium on the opposite side of the duct lumen.

Fig. 7 shows a cross-section of oyster intestine in which the epithelium of one arm was the site of a large focal lesion, while the epithelium of the opposite arm was uninvolved. Small particulate and diffuse nonparticulate fluorescence was seen in epithelial and connective tissues adjacent to the lesion, as well as within the intestinal lumen. This diffuse fluorescent signal decreased with distance from the lesion, although several fluorescent pathogen cells were seen free in the lumen of the uninvolved arm of the intestine. Similar observations of pathogen cells free within the gonoduct lumen (not pictured) suggested several possible routes of pathogen dissemination from infected hosts which would be coupled to normal excretory or spawning activities.

Small fluorescent particles were seen associated with epithelial cells and their apical cilia in a focal lesion of stomach epithelium shown in Fig. 8. Apical cilia and cells near the site of heaviest pathogen concentration showed evidence of degeneration, while cells and their cilia a short distance from the lesion appeared unaf- fected. The epithelium of the longitudinally sectioned and branching digestive gland distributing duct shown in Fig. 9 was heavily infected, yet the epithelia of absorptive tubules which surrounded the duct, and to which the duct communicates, showed few pathogen cells. The distribution of diffuse fluorescence was limited to connective tissues interstitial between absorptive tubules.

Rabbit antisera also labeled Perkinsus marinus cells produced in vitro. Fig. 10 shows immunoperoxidase staining of the hypnospore cell type used as the immunogen in this study. Epitopes labeled by rabbit antibodies appear black in this preparation by the precipitation of DAB-cobalt at sites of antibody/enzyme localization. An enzyme-linked reporter system was chosen over a fluorescent reporter system for this sample because $P$. marinus hypnospores possessed several autofluorescent components. Low-intensity, yellowgreen autofluorescence of the cell wall occurred upon excitation with blue light. A higher-intensity autofluorescence by large droplets or granules occurring within the cytoplasm and the eccentric vacuole was common. This second autofluorescent source was excited by a range of wavelengths spanning the spectrum from ultraviolet to green, and its emission wavelength (color) varied as a function of excitation wavelength. Results reported from studies utilizing fluorescent reporter molecules without controls for endogenous sources of sample fluorescence are suspect (e.g. Choi et al. 1991).

Fig. 10 demonstrates that rabbit antibodies bound to the external surface of the cell wall, to the plasma membrane and cell cytoplasm, and to the nuclear membranes and endosome of hypnospore immunogen cells. The strong correlation between dominant structures immunostained in RFTM-incubated hypnospores and in trophozoites present in host tissues suggested a close structural and biochemical homology between these cell types. Variable permeability of the thick hypnospore wall to immunoglobulin molecules was indicated in our preparations by the occurrence of some hypnospore cells showing an absence of immunostained internal elements, but typical immunostaining of the external wall surface.

Figs. 6 to 9. Crassostrea virginica infected by Perkinsus marinus. Fluorescence immunostained histological sections of infected oyster tissues counterstained with Evan's blue. Fig. 6. Cross-sectioned digestive gland distributing duct with a focal, epithelial lesion (arrow). Noncellular immunofluorescence is associated with epithelial cells involved by the lesion, but is absent from uninvolved epithelium opposite the lesion. Scale bar $=50 \mu \mathrm{m}$. Fig. 7 . Cross-sectioned intestine where the epithelium of one arm is heavily infected, while that of the other arm is uninvolved. Noncellular, diffuse immunofluorescence is seen in the epithelia, intestinal lumen, and connective tissues involved by the lesion. The signal decreases with distance from the lesion. Several fluorescent pathogen cells are free in the intestinal lumen (arrow) away from the lesion. Scale bar $=50 \mu \mathrm{m}$. Fig. 8 . Focal lesion of stomach epithelium. Only involved epithelial cells and their apical cilia show degenerative changes and minute, noncellular, inmunofluorescent particles (arrow). Scale bar $=50 \mu \mathrm{m}$. Fig. 9. Longitudinally sectioned and heavily infected digestive gland distributing duct. Epithelia of absorptive tubules surrounding the duct, and with which the duct communicates, are only lightly involved. Scale bar $=100 \mu \mathrm{m}$ 


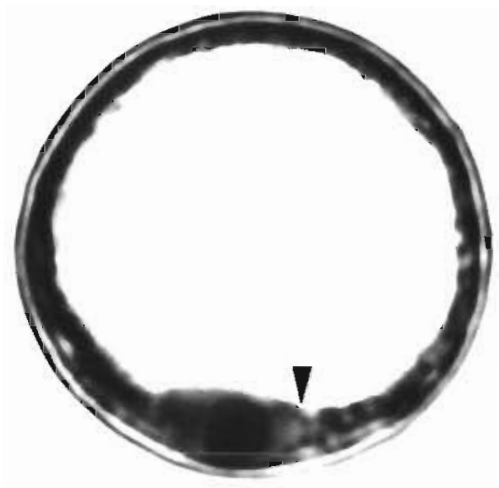

10

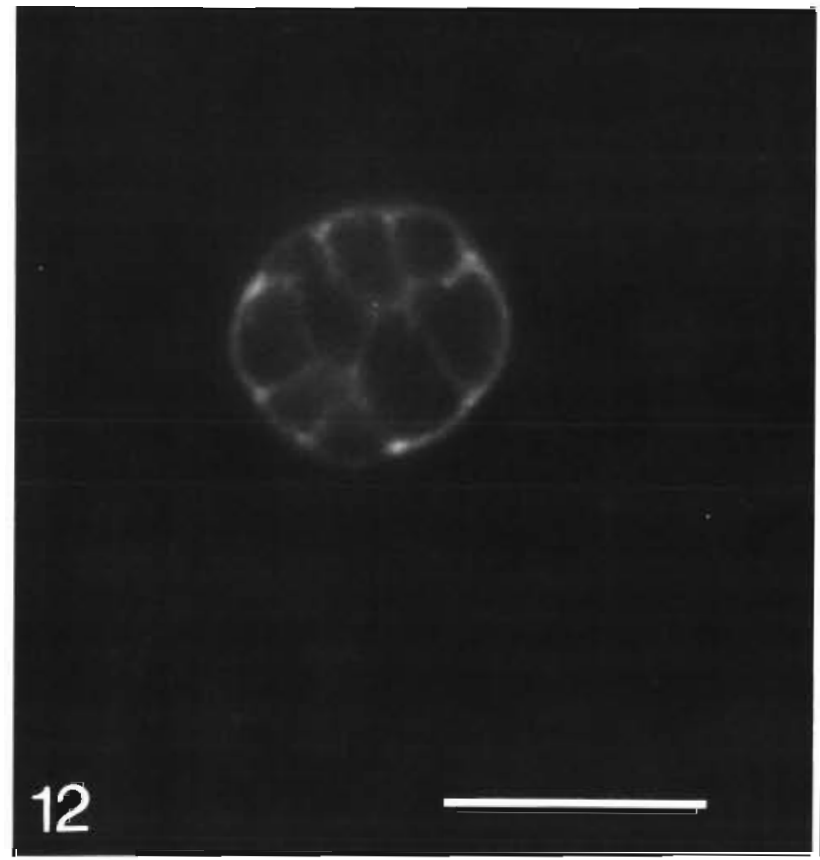

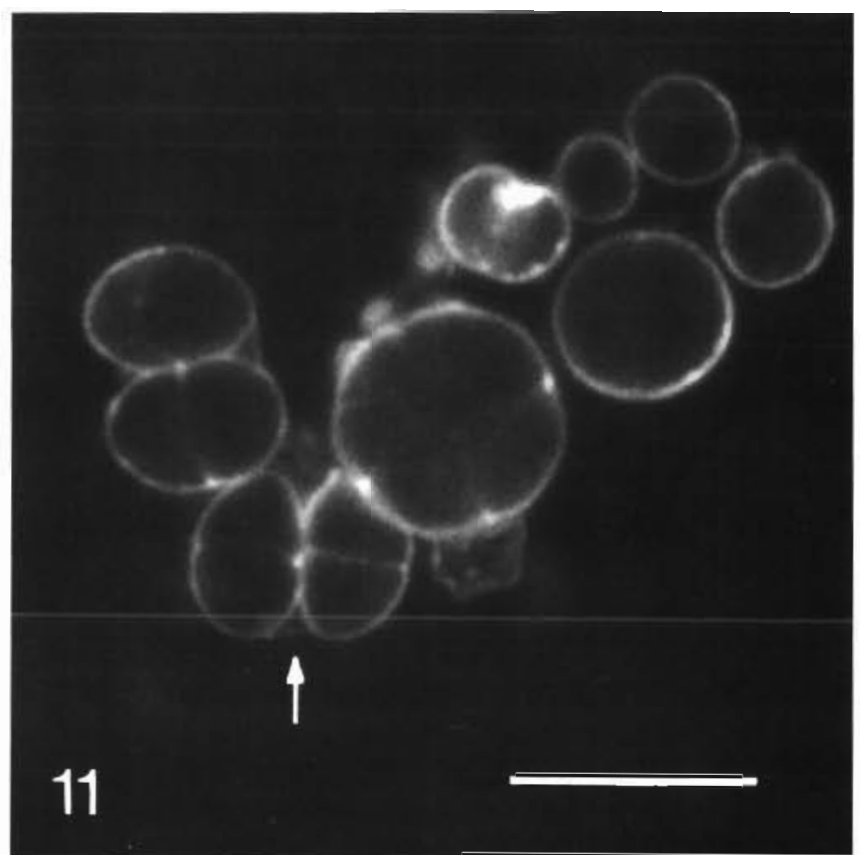

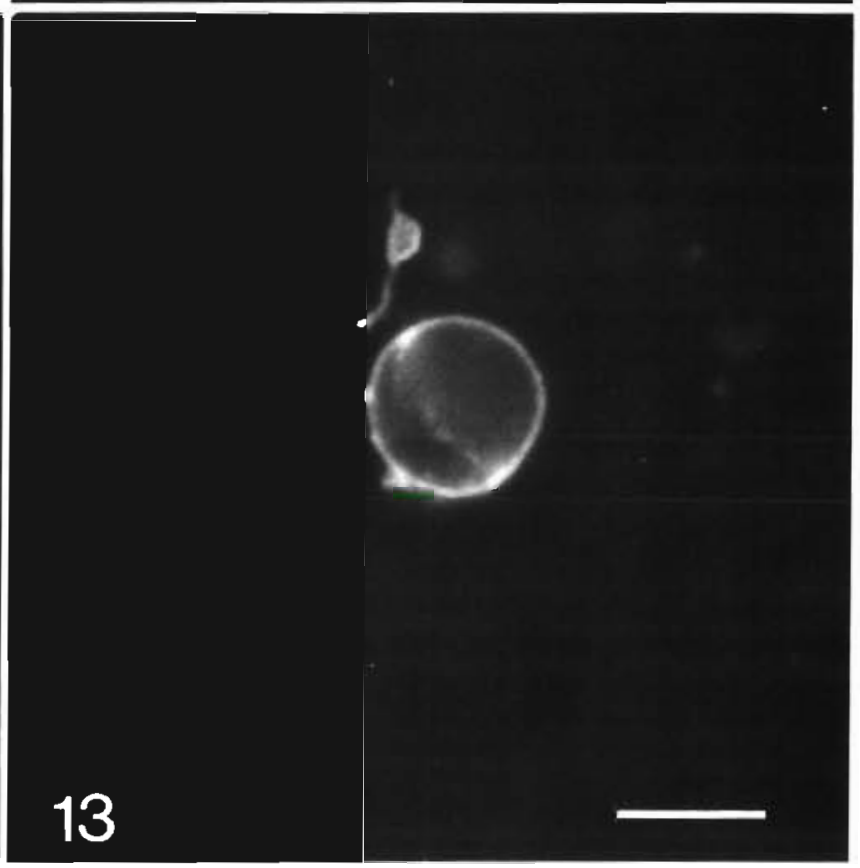

Figs 10 to 13. Perkinsus marinus in vitro. Figs. 10. Enzyme immunostained P. marinus hypnospore in vitro demonstrating antibody binding to the external wall surface, plasma membrane, cytoplasm, nuclear membranes (arrow), and endosome of an immunogen cell. Immunostained elements are black. Scale bar $=10 \mu \mathrm{m}$. Figs. 11 to 13. P. marinus proliferative cells produced in vitro following incubation of infected oyster hemolymph in SASW for $30 \mathrm{~d}$. All cells were fluorescence immunostained following immobilization on polycarbonate membranes. Fig. 11. Several 2- to 4-cell division figures showing surface immunostaining and shared membrane svstems (arrow). Scale bar $=1.0 \mathrm{um}$. Fig. 12. Multicellular division figure which is surface-immunostained and apparently bound by a common membrane. Scale bar $=10 \mu \mathrm{m}$. Fig. 13. Two-cell division figure and an immunostained biflagellate zoospore. Scale bar $=5.0 \mu \mathrm{m}$

Fluorescence immunostained proliferative cells produced in vitro by incubation of infected oyster hemolymph for $30 \mathrm{~d}$ in $20 \mathrm{ppt}$ SASW are shown immobilized on polycarbonate membranes in Figs. 11 to 13. Fig. 11 shows several 2-cell and 4-cell figures comprised of variably sized cells which appeared to be 
actively dividing. One apparent resuit of this division process was the production of multiple small cells from single large cells. Presumably, replication and division of genetic material preceded cell division. The presence of an apparent shared external membrane which was immunostained and enveloped several pairs of 2 cell figures suggested a common progenitor cell. Fig. 12 shows an immunostained multicellular figure (schizont) bound by a common membrane. The restriction of immunostaining to cell surfaces in these preparations suggested a low permeability of cell membranes to immunoglobulin molecules.

Fig. 13 shows a large cell bisected by a division furrow and a small, biflagellate zoospore. Zoospore flagellar morphology was not well demonstrated by either method used for zoospore immobilization. However, numerous similar flagellated cells were present in our immunostained preparations, and were presumed to represent motile cells observed in the SASW sample which was immobilized. These immunostained flagellated cells had dimensions $(1.3 \times 2.0 \mathrm{um})$ which were smaller than those described by Perkins \& Menzel (1967) $(2-3 \times 4-6 \mu \mathrm{m})$ for zoospores produced in sporangia following RFTM-incubation of pathogen cells. Our data showed that flagellated cells recognized by rabbit antibodies raised against Perkinsus marinus hypnospores were produced following simple incubation of axenic, infected oyster hemolymph in SASW. If proliferative cells shown immunostained in Figs. 11 \& 12 gave rise to motile zoospores, the developmental sequence may differ from that described by Perkins \& Menzel (1967), since sporangia were not observed in our preparations.

\section{Rabbit antibody reactions with other pathogens}

Patterns of rabbit antibody reactivity with a variety of protozoan pathogens which may share taxonomic affinities with Perkinsus marinus, or which may coinfect $P$. marinus-infected Crassostrea virginica, are shown in Table 2. Rabbit antisera did not react with Haplosporidium nelsoni coinfecting $C$. virginica with $P$. marinus infections. The antiserum also failed to recognize either Dermocystidium species infecting salmonid fishes. All Perkinsus species infecting $C$. virginica hosts from a wide range of geographical locations were labeled. Both Perkinsus species infecting clams from Chesapeake Bay were labeled. Perkinsus atlanticus infecting Ruditapes decussatus and Perkinsus olseni infecting Haliotis laevigata were labeled, but Perkinsus karlssoni infecting Argopecten irradians was not. Among taxonomically undifferentiated Perkinsus species infecting a range of Australian molluscs, antibody binding varied.

Although rabbit antibodies did not bind detectably to tissue epitopes present in the host from which the immunogen was isolated, they did appear to bind, in various degrees, to host tissue epitopes in several of the solicited samples. Whether these binding reactions represented antibody affinities for normal host tissue epitopes, affinities for exported pathogen components or degradation products, or both, has not been determined.

$D A B$ is a sensitive reagent for the localization of horseradish peroxidase, producing a brown precipitate at sites of enzyme localization. However, in sectioned Crassostrea virginica tissues, both the color and mor-

Table 2. Pathogen species, host species, sample source, and Rabbit $\alpha$ Perkinsus marinus binding reaction for samples of aquatic host tissues infected with selected protozoan pathogen species. For full genus names see Table 1

\begin{tabular}{|c|c|c|c|}
\hline Pathogen species & Host species & Geographic source & $\begin{array}{l}\text { Rabbit } \alpha P \text { marinus } \\
\text { antibody binding }\end{array}$ \\
\hline H. nelsoni & C. virginica & MD, USA & - \\
\hline P. marinus & C. virginica & $A L, U S A$ & + \\
\hline P. marinus & C. virginica & MD, USA & + \\
\hline$P$. marinus & C. virginica & MA, USA & + \\
\hline Perkinsus sp. & C. virginica & HI, USA & + \\
\hline Perkinsus sp. & M. balthica & MD, USA & + \\
\hline Perkinsus sp. & M. arenaria & MD, USA & + \\
\hline P. atlanticus & R. decussatus & Portugal & + \\
\hline P. olseni & H. laevigata & Australia & + \\
\hline Perkinsus sp. & T. maxima & Australia & + \\
\hline Perkinsus sp. & T. crocea & Australia & + \\
\hline Perkinsus sp. & K. rhytiphora & Australia & - \\
\hline Perkinsus sp. & C. pacificus & Australia & - \\
\hline Perkinsus sp. & A. trapezia & Australia & - \\
\hline P. karlssoni & A. irradians & NB, Canada & - \\
\hline Dermocystidium sp. & S. salar & CA, USA & - \\
\hline D. salmonis & O. tshawytscha & OR, USA & - \\
\hline
\end{tabular}


phology of some Perkinsus marinus cell types stained with DAB alone are similar to lipofuscin (ceroid) granules normally present in some oyster cells, and whose abundance increases as a result of $P$. marinus infection (Mackin 1951). Use of cobalt metal enhancement shifts the color of the DAB reaction product toward black (Hsu \& Soban 1982). This reaction product provided good differentiation of immunostained elements when used in conjunction with a standard H\&E counterstain, and used to stain either histological or cytological samples

\section{DISCUSSION}

The results of this study demonstrate that Perkinsus marinus hypnospores isolated by the simple methods described are functionally free of host oyster antigenic determinants, and are immunogenic. At least some antibodies elicited in mammals following exposure to this immunogen bind to epitopes on all known $P$. marinus cell types. Polyclonal antisera bound to hypnospores produced in vitro, as well as to mature trophozoites and proliferating immature trophozoite rosettes in fixed tissue sections.

In addition to the known Perkinsus marinus cell types described above, rabbit antisera bound to a soluble, and to a noncellular, small particulate substance present in tissues adjacent to foci of pathogen proliferation. This signal was absent in tissues of uninfected oysters, and decreased with distance from focal lesions in infected oyster tissues.

Histopathological observations (Mackin 1951) and the observation of accelerated necrosis of gill explants from infected oysters (Ray et al. 1953) led several earlier investigators to hypothesize that pathogenesis of Perkinsus marinus infections is mediated by soluble Iytic factors exported by the pathogen. While the existence and activities of these hypothetical virulence factors have not been demonstrated, our results show that one or more soluble factors are exported to host oyster tissues by $P$. marinus, and that some share common epitopes with our hypnospore immunogen. The activities and compositions of these immunoreactive substances remain to be determined, as do their potential roles in pathogen physiology and disease pathogenesis.

Rabbit antisera also bound to motile zoospores produced in vitro, as well as to nonmotile proliferative cells resembling some described by Mackin (1962) from similar preparations. Analogous serological or antigenic homogeneity between motile and nonmotile cells of Labyrinthuloides haliotidis, a protistan parasite of abalone, has been demonstrated by Bower et al. (1989).
Immunostained flagellated cells produced by our methods $(1.3 \times 2.0 \mu \mathrm{m})$ were smaller than those described by Perkins \& Menzel (1967) (2-4 × 4-6 um). Whether this difference in dimensions reflects distinctions in function or ontogeny of motile Perkinsus marinus cells, or whether it is due to differences in nutritional conditions under which zoospore differentiation occurred, is not known. The appearance of nonmotile dividing cells in our preparations as they approach zoospore dimensions suggests that the end result of the proliferative process documented here may be the production of motile cells by a pathway which is distinct from that described by Perkins \& Menzel (1967), and which does not require exposure to RFTM. Alternatively, the nonmotile proliferative cells occurring together with motile zoospores in our seawater cultures of infected oyster hemolymph may represent a separate capacity for heterotrophic pathogen proliferation outside the host environment. Whether these cells are infective has not been tested.

Previous attempts to develop Perkinsus marinusspecific rabbit antisera have been made by at least 2 groups. In one effort, the immunogen used was a detergent-solubilized extract of sonicated $P$. marinus hypnospores, which had been purified from RFTM incubated with infected oyster tissues. Rabbit antisera produced using this immunogen bound to host tissue epitopes, but not to pathogen cells in cryosections of infected host tissues (Choi et al. 1991). A separate effort used whole, washed, but unfixed $P$. marinus hypnospores isolated from RFTM-incubated oyster tissues following trypsin digestion. Rabbit antisera harvested after multiple injections of 1.0 to $5.0 \times 10^{6}$ pathogen cells showed no detectable antibody titers to pathogen epitopes when tested by immunostaining of fixed, infected tissues (E. M. Burreson pers. comm.).

Differences between the results obtained in previous efforts and those reported for the present study may reflect important differences in the methodology used to isolate and purify the immunogen. Since oyster hemocytes die and lyse over several days in RFTM, immunogenic pathogen cells were obtained during the present study without recourse to sonication, detergent extraction, or enzymatic digestion. The use of such procedures may affect removal or alteration of important antigenic determinants. The use of infected oyster hemolymph as a source of pathogen cells may also allow more thorough separation of pathogen and host components by minimizing both the relative proportion and the diversity of host determinants copurifying with pathogen cells

Presentation of the immunogen in particulate form was expected to be immunostimulatory. That intracellular antigenic determinants were processed and presented by immunized animal macrophages is evi- 
denced by strong binding affinities of polyclonal antisera for intracellular pathogen epitopes. Variability in immunostaining of intracellular epitopes both among the different cell types tested, as well as within single cell types, suggested variable permeability of pathogen cell membranes or walls to immunoglobulins. Staining of intracellular epitopes was most consistent in cells which had been processed histologically. The enhanced availability of intracellular epitopes in histological samples may derive from differences in fixation, organic solvent extraction, exposure to heat, or physical breach.

In the present effort, Perkinsus marinus hypnospores were sedimented extensively at low relative centrifugal force, allowing smaller host cell particulates and soluble components to be discarded with supernates. That some normal host components copurified with the hypnospore immunogen is suggested by the measurable titers of rabbit antibodies binding to oyster tissue epitopes in ELISA assays. However, the measurement of identical titers in preimmune sera, and their failure to increase with exposure to the immunogen both confirm that they represent spurious antibody binding at high serum concentrations. While minor antibody binding to apical surfaces of mucus-secreting epithelia was infrequently observed in immunostained histological sections of oyster tissues, antibody binding to hemocytes or soluble hemolymph components was never detected.

Although polyclonal antisera from hyperimmunized splenocyte donor mice used in hybridoma production showed strong binding specificities for both surface and intracellular epitopes of pathogen cells in histological sections, cloned murine hybridomas were found to secrete MABs which recognized epitopes which were apparently unique to the hypnospore immunogen. The binding specificities of these MABs suggest limited utilities in detection of a range of pathogen cell types. Since binding specificities of polyclonal antisera produced in both mice and rabbits indicate the presence of common epitopes shared by Perkinsus marinus hypnospores and other pathogen cell types, development of hybridoma screening assays which selectively detect specificities for these common epitopes will permit the generation of MABs with broader utilities.

Results of the present study suggest that several subcellular components of the Perkinsus marinus hypnospore cell are good immunogen candidates for further antibody production efforts. Highly immunogenic hypnospore epitopes which appear to be shared by other $P$. marinus cell types are associated with the cell and nuclear membranes, cytoplasmic elements, and the nuclear endosome. Refinement of methods for pathogen cell fractionation will facilitate the development of selective antibody screening assays, and will also permit needed studies of pathogen biochemical composition, physiology, and genetics. Development of methods for in vitro propagation of $P$. marinus cells will similarly support such efforts.

Antibody binding specificity is not an absolute quality. Failure of our polyclonal antisera to recognize any epitopes on some tested protozoan pathogens suggests. but does not confirm, complete dissimilarity with Perkinsus marinus. Positive binding reactions indicate the presence of one or more epitopes common to $P$. marinus hypnospores. The broad range of Perkinsus species with which our antibodies reacted serves to substantiate taxonomic distinction of the group based on morphology and their unique response to RFTM exposure. However, the failure of our antibodies to recognize any epitopes on several Perkinsus species indicates that significant antigenic heterogeneity exists among Perkinsus-like organisms infecting aquatic molluscan hosts.

Binding specificities of rabbit polyclonal antibodies for various protozoan pathogens infecting molluscan hosts in Chesapeake Bay indicate some degree of serological homogeneity among local Perkinsus species. Although morphological (Perkins 1988, Valiulis \& Mackin 1969) and epizootiological (Ray 1954) differences have been cited in efforts to differentiate these pathogens, our data do not support a distinction. Failure of our antisera to bind to Haplosporidium nelsoni, another significant pathogen of Crassostrea virginica in Chesapeake and Delaware Bay waters, indicates that these antibodies will be useful in selectively detecting $P$. marinus in diagnostic samples from this geographic area.

Polyclonal antibodies to Perkinsus marinus recognized both $P$. atlanticus and $P$. olseni, but failed to bind to $P$. karlssoni, indicating a degree of similarity among the first 3 Perkinsus species that is not shared by $P$. karlssoni. Failure of our antibodies to recognize 2 Dermocystidium species infecting salmonid fishes further supports other evidence (Perkins 1988, Olson et al. 1991) that at least some Dermocystidium species infecting fishes are unrelated to apicomplexans infecting molluscan hosts. Variability in antibody binding among Perkinsus species infecting a variety of Australian molluscs indicates that diverse parasite taxa were represented in the samples we examined.

Throughout this report, historical terminology for Perkinsus marinus cell types has been used for clarity, in spite of our recognition that many of these terms are incorrectly applied and potentially misleading. In the absence of full knowledge of the $P$. marinus life cycle, and of genetic and functional characteristics of its various cell types, adoption of terminology consistent with the apicomplexan affinities of this organism involves embracing untested assumptions. It is our hope that, 
through development of a specific probe for $P$. marinus, we have facilitated the resolution of a comprehensive knowledge of this pathogen's life cycle, and promoted adoption of a consistent terminology for its stages.

Acknowledgements. This work was funded, in part, under Project NA90AA-D-FM791 of the Federal Oyster Disease Research Program administered by the U.S. Department of Commerce, NOAA, NMFS. We thank Dr George Krantz for his support and critical input. We also thank Dr Carl Sinderman, Dr George Krantz, Ms Jane Keller, and Ms Rosalee Hamilton for critical reviews of the manuscript.

\section{LITERATURE CITED}

Andrews, J. D. (1954). Notes on fungus parasites of bivalve molluscs in Chesapeake Bay. Proc. natl Shellfish. Assoc. 45: $157-1.63$

Andrews, J. D. (1988). Epizootiology of the disease caused by the oyster pathogen, Perkinsus marinus and its effects on the oyster industry. Am. Fish. Soc. Spec. Publ. 18: 47-63

Azevedo, C. (1989). Fine structure of Perkinsus atlanticus n. sp. (Apicomplexa, Perkinsea) parasite of the clam, Ruditapes decussatus from Portugal, J. Parasitol. 75: $627-635$

Bower, S. M., Whitaker, D. J., Elston, R. A. (1989). Detection of the abalone parasite Labyrinthuloides haliotidis by a direct fluorescent antibody technique. J. Invertebr Pathol. 53: 281-283

Choi, K.-S., Lewis, D. H., Powell, E. N., Frelier, P. S., Ray, S. M. (1991). A polyclonal antibody developed from Perkinsus marinus hypnospores fails to react with other life stages of $P$. marinus in oyster (Crassostrea virginica) tissues. J. Shellfish Res. 10: 411-415

Choi, K.-S., Wilson, E. A., Lewis, D. H., Powell, E. N., Ray, S. M. (1989). The energetic cost of Perkinsus marinus parasitism in oysters: quantification of the thioglycollate method. J. Shellfish Res. 8: 125-131

Chu, F.-L. E., Greene, K. H. (1989). Effect of temperature and salinity on in vitro culture of the oyster pathogen, Perkinsus marinus (Apicomplexa: Perkinsea). J. Invertebr. Pathol 53: 260-268

Gauthier, J. D., Fisher, W S. (1990). Hemolymph assay for diagnosis of Perkinsus marinus in oysters Crassostrea virginica (Gmelin). J. Shellfish Res. 9: 367-371

Goggin, C. L., Lester, R. J. G. (1987). Occurrence of Perkinsus species (Protozoa, Apicomplexa) in bivalves from the Great Barrier Reef. Dis. aquat. Org. 3: 113-117

Harlow, E., Lane, D. (1988). Antibodies: a laboratory manual. Cold Spring Harbor Laboratory, New York

Haskin, H. H., Stauber, L. A., Mackin, J. G. (1966). Minchinia nelsoni $\mathrm{n}$. sp. (Haplosporida, Haplosporidiidae): causative agent of the Delaware Bay oyster epizootic. Science 153: $1414-1416$

Hedrick. R. P., Friedman, C. S., Modin, J. (1989). Systemic

Responsible Subject Editor: A. K. Sparks, Seattle,

Washington, USA. infection in Atlantic salmon, Salmo salar with a Dermocystidium-like species. Dis. aquat. Org. 7: 1.71-177

Hsu, S.-M., Soban, E. (1982). Color modification of diaminobenzidine (DAB) precipitation by metallic ions and its application for double immunohistochemistry. J. Histochem. Cytochem. 30: 1079-1082

Kern, F. G., Sullivan, L. C., Takata, M. (1973). Labyrinthomyxa-like organisms associated with mass mortalities of oysters, Crassostrea virginica, from Hawaii. Proc. natl Shellfish. Assoc. 63: 43-46

Lester, R. J. G., Goggin, C. L., Sewell, K. B. (1990). Perkinsus in Australia. In: Perkins, F. O., Cheng, T. C. (eds.) Pathology in marine science. Academic Press, London, p. 189-199

Mackin, J. G. (1951). Histopathology of infection of Crassostrea virginica (Gmelin) by Dermocystidium marinum Mackin, Owen and Collier. Bull. mar Sci. Gulf Caribb. 1. 72-87

Mackin. J. G. (1962). Oyster diseases caused by Dermocystidium marinum and other microorganisms in Louisiana. Pub. Inst. mar. Sci. Univ. Tex. 7. 132229

Mackin, J. G., Owen, H. M., Collier, A. (1950). Preliminary note on the occurrence of a new protistan parasite, Dermocystidium marinum $\mathrm{n}$. $\mathrm{sp}$. in Crassostrea virginica (Gmelin). Science 111: 328-329

McGladdery, S. M., Cawthorn, R. J., Bradford, B. C. (1991). Perkinsus karlssoni n. sp. (Apicomplexa) in bay scallops Argopecten irradians. Dis. aquat. Org. 10: 127-137

Olson, R. E., Dungan, C. F., Holt, R. A. (1991). Water-borne transmission of Dermocystidium salmonis in the laboratory. Dis. aquat. Org. 12: 41-48

Pauley, G. B. (1967). Prespawning adult salmon mortality associated with a fungus of the genus Dermocystidium J. Fish. Res. Bd Can. 24: 843-848

Perkins, F. O. (1988). Structure of protistan parasites found in bivalve molluscs. Am. Fish. Soc. Spec. Publ. 18: 93-111

Perkins, F. O., Menzel, R. W. (1967). Ultrastructure of sporulation in the oyster pathogen Dermocystidium marinum J. Invertebr. Pathol. 9: 205-229

Ray, S. M. (1952). A culture technique for the diagnosis of infections with Dermocystidium marinum Mackin, Owen, and Collier in oysters. Science 116: 360-361

Ray, S. M. (1954). Biological studies of Dermocystidium marinum. Rice Inst. Pamph., Spec. Issue, Monogr Biol Rice Institute, Houston, TX

Ray, S. M. (1963). A review of the culture method for detecting Dermocystidium marinum, with suggested modifications and precautions. Proc natl Shellfish. Assoc. 54: 55-69

Ray, S. M., Mackin, J. G., Boswell, J. L. (1953). Quantitative measurement of the effect on oysters of disease caused by Dermocystidium marinum. Bull mar. Sci. Gulf Caribb. 3: 6-33

Valiulis, G. A., Mackin, J. G. (1969). Formation of sporangia and zoospores by Labyrinthomyxa sp. parasitic in the clam. Macoma balthica. J. Invertebr. Pathol. 14: 268-270

White, M. E., Powell, E. N., Ray, S. M., Wilson, E. A. (1987). Hostto-host transmission of Perkinsus marinus in oyster (Crassostrea virginica) populations by the ectoparasitic snail Boonea impressa (Pyramidellidae). J. Shellfish Res. 6: $1-5$

Manuscript first received: May 11, 1992

Revised version accepted: September 18, 1992 